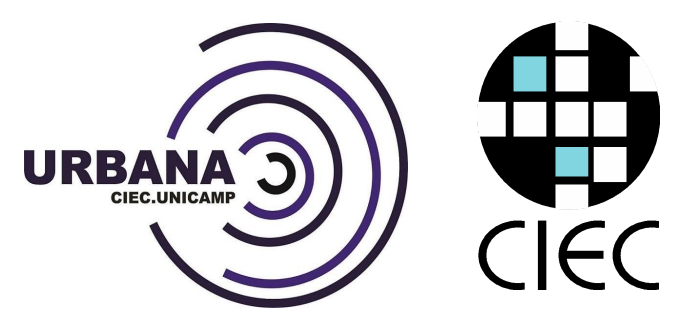

URBANA: Revista Eletrônica do Centro Interdisciplinar de Estudos sobre a Cidade

Ana Clara Sousa e Silva; Matheus Silva Nascimento; Beatriz Santos Alves Lopes Boaventura; Isaura Oliveira Figueiredo

myanaclara@gmail.com; matheus.tropicalia.atlas@gmail.com; beatrisantos.sb@gmail.com; isauraoliveirafigueiredo@gmail.com | Universidade do Estado da Bahia

\title{
A cidade enquanto obra de arte e a arte enquanto revelação do sujeito
} Além da técnica e da estética, um olhar para a subjetividade

The city as artwork and the art as revelation of the subject

Beyond technique and aesthetics, a look at subjectivity

La ciudad como obra de arte y el arte como revelación del los sujetos

Más allá de la técnica y la estética, una mirada a la subjetividad

1. A cidade como obra de arte ou apenas mais uma obra de arte na cidade? - Considerações iniciais

Diante de vários conceitos, e de um cartesianismo supressor da arte, ou o que a restringiu à um olhar estético, nunca a colocou enquanto possibilidade metodológica de revelação dos objetos em sua natureza sociocultural e política. Historicamente confinada a espaços específicos, a definições restritas a técnica e a função determinada, somente na década de 1960 do Século 20 com o advento do estilo contemporâneo - e, consequentemente a ruptura com um estilo anterior (GOMBRICH, 2010) - é que há a absorção de 
conceitos construídos e/ou ratificados onde a arte se reencontra com suas possibilidades de instrumento epistemológico.

Ao iniciarmos uma reflexão sobre os aspectos contemporâneos da arte, percebemos que o alargamento de suas funções sociais, para além do olhar estético, a recoloca não somente como instrumento fundamentalmente sociocultural e político, mas, a princípio, redireciona a mesma, a questões de natureza orgânica e epistemológica (GOMBRICH, 2010), visto que a constitui como elemento analítico de apreensão do espaço e do sujeito. Como podemos afirmar a partir da análise de Eco (1968):

Num contexto cultural em que a lógica de dois valores não é mais o único instrumento possível de conhecimento, mas onde se propõem lógicas de mais valores, que dão lugar, por exemplo, ao indeterminado como resultado válido da operação cognoscitiva, nesse contexto de ideias eis que se apresenta uma poética da obra de arte desprovida de resultado necessário e previsível, em que a liberdade do intérprete joga como elemento daquela descontinuidade que a física contemporânea reconheceu não como motivo de desorientação, mas como aspecto eliminável de toda verificação científica e como comportamento verificável e insofismável do mundo subatômico. (ECO, 1968, p.56-57)

A relação entre a arte - como elemento revelador do espaço latente - e a cidade, em seus múltiplos aspectos, é uma questão analítica recente, ainda que a arte há muito tenha sua produção atrelada ao meio urbano. Não se trata de perceber esta relação por si só como objeto, ou mais restritamente, como objeto na sua própria natureza, como coloca Argan (1992), que analisa a cidade como um construto humano, dotado de uma técnica que, portanto, acontece quanto fato histórico isolado na forma. Tal análise se perde a partir do conceito de arte mais recente, quando esta passa a ser pensada (GOMBRICH, 2010) na relação entre o observador, o sujeito, e a obra nos obrigando necessariamente a rever o emprego de uma técnica, sem negá-la, mas, sugerindo a evocação de uma participação na construção do espaço vivido. A arte não consiste mais em um objeto 
para você olhar, achar bonito, mas para uma preparação para a vida (CLARK, Lygia). ${ }^{1}$

A questão aqui proposta não nega a afirmação de Argan (1992), mas a analisa diante do conceito de lugar constituído por Santos (2002), e ratificada por outros autores que relacionam o espaço, a apropriação e subjetivação. Neste sentido, poderíamos afirmar que nem toda cidade pode ser compreendida como obra de arte pois, ainda que em sua episteme o seja, nem sempre se constitui a partir deste acento orgânico. Também cabe a reflexão que, mesmo a arte enquanto objeto inserido no espaço citadino, nem sempre se revela- ou é revelada como tal. Portanto, existe algum elemento na cidade em si mesma que é capaz de retirá-la deste lugar de natureza epistemológica de obra de arte e, consequentemente, de seu lugar enquanto obra de natureza estética.

Ao reunir o conceito de lugar ao conceito de cidade, o que pretendemos é refletir qual é o elemento capaz de anular a natureza da cidade e da arte enquanto objetos que guardam em si mesmos relações que os revelam. E, se tal condição, não reside nem na obra, e nem na cidade, só pode estar posta em outro suporte desse tripé - o sujeito.

(...) descrita por meio de 'formas da consciência': o eu, a pessoa, o cidadão e o sujeito epistemológico. O eu é a identidade, formada das vivencias psíquicas; é a forma de conhecimento singular. [...]. A pessoa é a consciência moral. [...]. O cidadão é a consciência política. [...]. O sujeito epistemológico é a consciência intelectual. [...]. A subjetividade assim composta (...) é a instancia da qual o homem (empírico ou abstratamente genérico) deve participar. Se conseguir isso, autenticamente, torna-se sujeito - 'aquele que é consciente de seus pensamentos e responsável pelos seus atos' (...). (ECO, 1968, p.74)

Este é necessariamente investigado aqui de modo imbricado aos elementos de análise anteriores, visto que na condição da contemporaneidade, o sujeito se confunde com a própria obra, e esta com a cidade, enquanto lugar. Podemos afirmar que, diante do

\footnotetext{
1 Retirado de: https://www. pensador.com/frase/MTgzNDEyMw. Acesso em 19 ago.2019.
} 
conceito de arte que reúne em si questões para além da forma, o que a determina enquanto natureza é o modo pelo qual o sujeito se apropria do objeto (GOMBRICH, 2010), e o revela, revelando-se a si e ao espaço.

O que possibilita esse conceito não é então o olhar que o sujeito lança, é o modo e como o sujeito se apropria desse espaço, isto porque não é uma relação de exteriorização entre sujeito e objeto, tendo em vista que ambos - sujeito e objeto - são ressignificados nessa relação. Ao incorporarmos ao conceito de cidade encontrado em Argan (1992), o conceito de lugar, o que propomos é ir para além dos paradigmas modernos, em que, o que existe é um objeto de arte na sua natureza atemporal e cristalizada limitado ao espaço, apenas na sua dimensão física, junto ao capital como forma de exploração material e apropriação de riquezas - ou seja, observando a arte para além de uma forma imposta, percebemos que tal apropriação não nasce no cartesianismo moderno, mas nas demandas subjetivas da contemporaneidade.

Assim, é preciso que compreendamos que, quando o autor promove o entendimento da cidade enquanto objeto de arte, este evoca a técnica e o espaço como atributos necessários, mas não pressupõe a interação entre o sujeito e a obra, o que fica determinado no conceito "Miltoniano" de lugar. Daí a necessidade de um exame de aproximação entre os dois conceitos - lugar e cidade.

Existe, é claro, um encantamento poético em vermos a cidade enquanto obra de arte, e neste instante podemos admitir que essa visão de totalidade promovida pela arte, possibilita por exemplo a visão do espaço que a geografia procura, o homem que a história analisa, enfim os vários discursos da ciência. Então a arte em suas possibilidades múltiplas e subjetivas é fundamental a vida, tanto quanto a cidade, e aí reside o modo do assentamento de um sobre o outro, sem no entanto distancia-la, de modo a excluí-la das possibilidades de objeto de compreensão do espaço e do sujeito. 
Investigamos, pois, que elemento é este que diante das reflexões "Arganianas", promovem por vezes a urgência de averiguação conceitual. Visto que, não é só na técnica e na forma que se imprimem a revelação do espaço que determinam tal conceito de cidade, já compreendemos que existe a necessidade de colocação de um terceiro elemento, responsável por uma revisita conceitual - o sujeito. Isto porque não é a obra em si, ou ainda, o espaço em si mesmo, que revela a condição de arte da cidade. Mas, esta é revelada à medida que o sujeito mediado tanto pelo espaço quanto pela obra - como objeto urbano - dá significado a estes e revela-se nestes. E para existir uma relação entre o mesmo, que permita a este revelar-se é preciso verificar elementos de um sentir cotidiano do espaço subjetivado e constituído pelo sujeito, tais como: a temporalidade, o modo de ocupação e uso do solo, bem como a forma de apropriação do capital cultural e simbólico.

Deste modo fica claro, que não se trata aqui da negação do conceito do autor, mas antes da compreensão que tal afirmativa, ao determinar a cidade enquanto obra de arte, não examina que a natureza deste espaço é latente, mas por vezes é reprimida pelo modo de apropriação, ficando assim sem revelar-se, o que somente acontece na interação com o sujeito.

E, se tal interação, a princípio, é facilitada pela percepção de objetos que ratificam a natureza da cidade, e impulsionam o sujeito a interagir com o espaço vivido, porque ainda assim, a natureza da cidade continua imersa nas suas outras tantas formas de revelar-se? O que impede a cidade revelar-se enquanto obra de arte diante de um sujeito que compõe a ela mesma ao tempo em que a traduz?

Os elementos de uma paisagem urbana que nos impede de percebermos a real relação entre espaço-arte-sujeito, descaracterizando, por vezes, a cidade diante da sua natureza, pois a paisagem é compreendida conforme traz Ferrara (2012), como elemento dotado unicamente de visualidade, ou seja, apenas contempla-se a cidade e não necessariamente se vive a mesma. 
Sabemos que a contemplação diz de aquietar-se para ver o outro, e não de misturar-se a ele, verbo elementar na compreensão contemporânea de arte. Para sairmos do estado de contempladores da paisagem, e a compreendermos enquanto apropriação humana do espaço, é primordial a relação de pertencimento ao lugar. A paisagem não como elemento da lembrança, mas como elemento de memória conforme traz Pollack (1989), quase sempre revisitada, é o que nos permite a revelá-la como nosso lugar.

\section{Metodologia da pesquisa}

Sendo a primeira parte de uma proposta de pesquisa mais ampla de mapeamento e análise das obras de arte da cidade de Salvador, a metodologia aqui elaborada é produto de um contínuo processo de construção, se dividindo até o momento em cinco etapas. A primeira delas é o recorte das obras a serem analisadas, isto se dá tanto pela necessidade de gestão da escala territorial a ser analisada, quanto pelas imposições derivadas das observações feitas em campo que constituem uma das bases da antropologia urbana, sendo assim, estudaremos o impacto da implantação de uma obra de arte numa escala de vizinhança.

No que tange as obras em si, as mesmas estão localizadas em áreas as quais podem ser compreendidas como "urbanizadas". O processo de seleção e análise parte de rodas conversas do grupo de pesquisa privilegiando as de naturezas bem específica e distinta, com o intuito de demarcar diferenças, quer seja pela fonte de financiamento (privado, público, encomendado, licitado, de manutenção própria do artista, etc), quer seja pelo sítio o qual se encontram implantadas, os diferentes pontos nodais, marcos, vias, ou seja, os elementos os quais Lynch (1997) traz por exemplo, como percursores de uma leitura da paisagem urbana.

A finalidade aqui é de obter diferentes cenários para se analisar, ou seja, compreender as diferentes relações que são formadas com uma manifestação artística material ou imaterial numa 
área predominantemente residencial, comercial ou até mesmo numa zona de interesse artístico e cultural, não impedindo a existência de ocupações e usos mistos do solo que possibilitam igualmente diferentes leituras da função social da arte e sua relação com o espaço.

Para esse artigo em específico foram "selecionadas" duas expressões artísticas materiais classificadas como esculturas feitas por dois artistas plásticos Baianos; a primeira, de financiamento privado, intitulada " A Mãe Baiana" de autoria de Carybé, localizada num trecho da avenida Tancredo Neves no bairro da Pituba (vide figura 01), e a segunda, encomendada por um órgão público, de nome "As meninas do Brasil" de Eliana Kertész, localizada no final da avenida Ademar de Barros no bairro de ondina (vide figura 02). Por fim, foi estudada igualmente uma poligonal numa área de interesse artístico e cultural $^{2}$ correspondente ao trecho do Largo de Santana ao Mariquita no Bairro do Rio Vermelho (vide figura 03).

${ }^{2}$ Vide Lei de Uso, Ordenamento e Ocupação do solo urbano de Salvador (LOUOS) - Lei n.9148 - sancionada em 08 de setembro de 2016. 


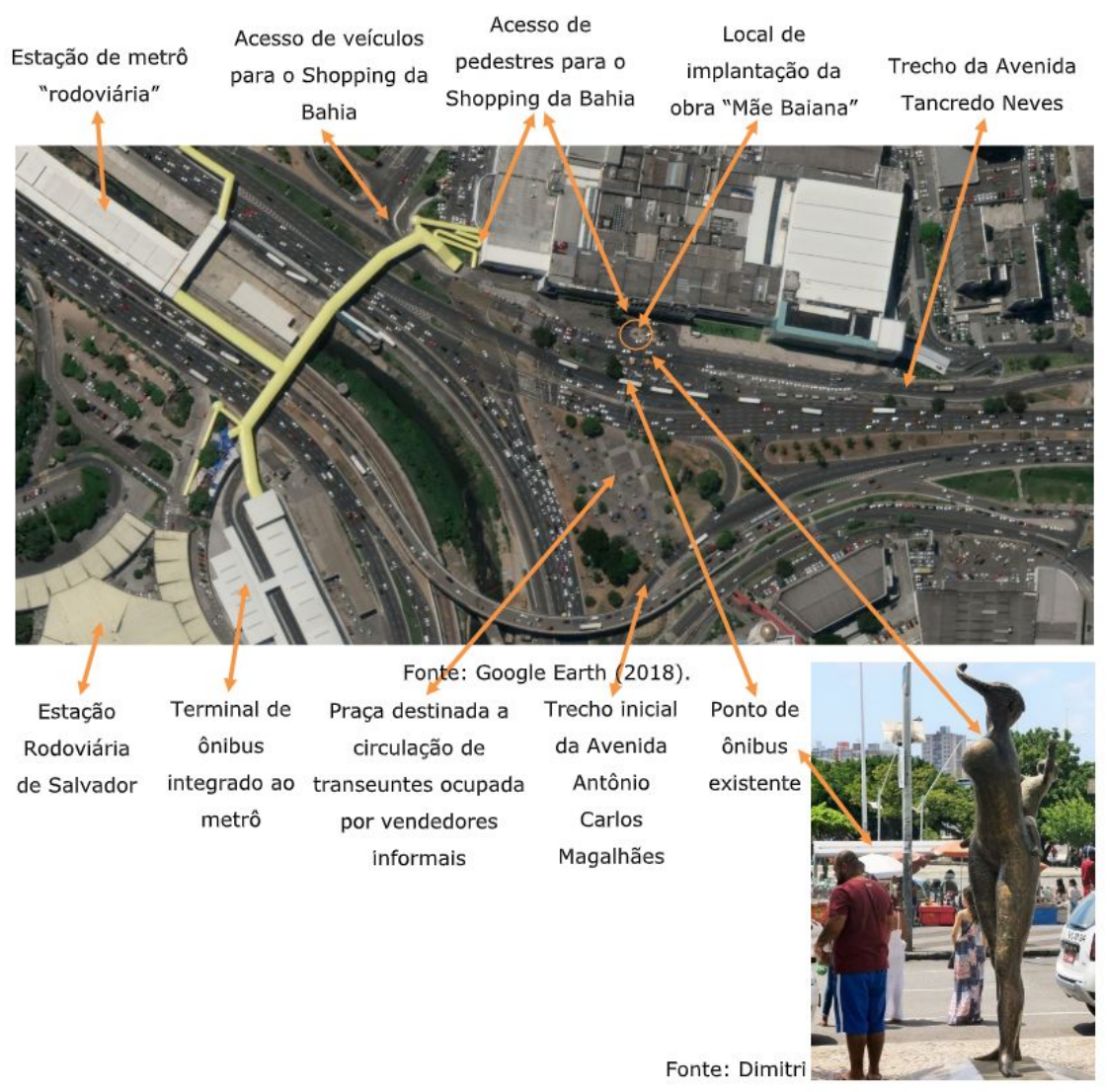

Figura 01: Esquema visual indicando o local de implantação da escultura "A Mãe Baiana" com destaque para algumas vias e equipamentos urbanos de importância na localidade. Acima imagem via satélite e abaixo foto da obra.

Fonte: Elaborado pelos autores (2019). 


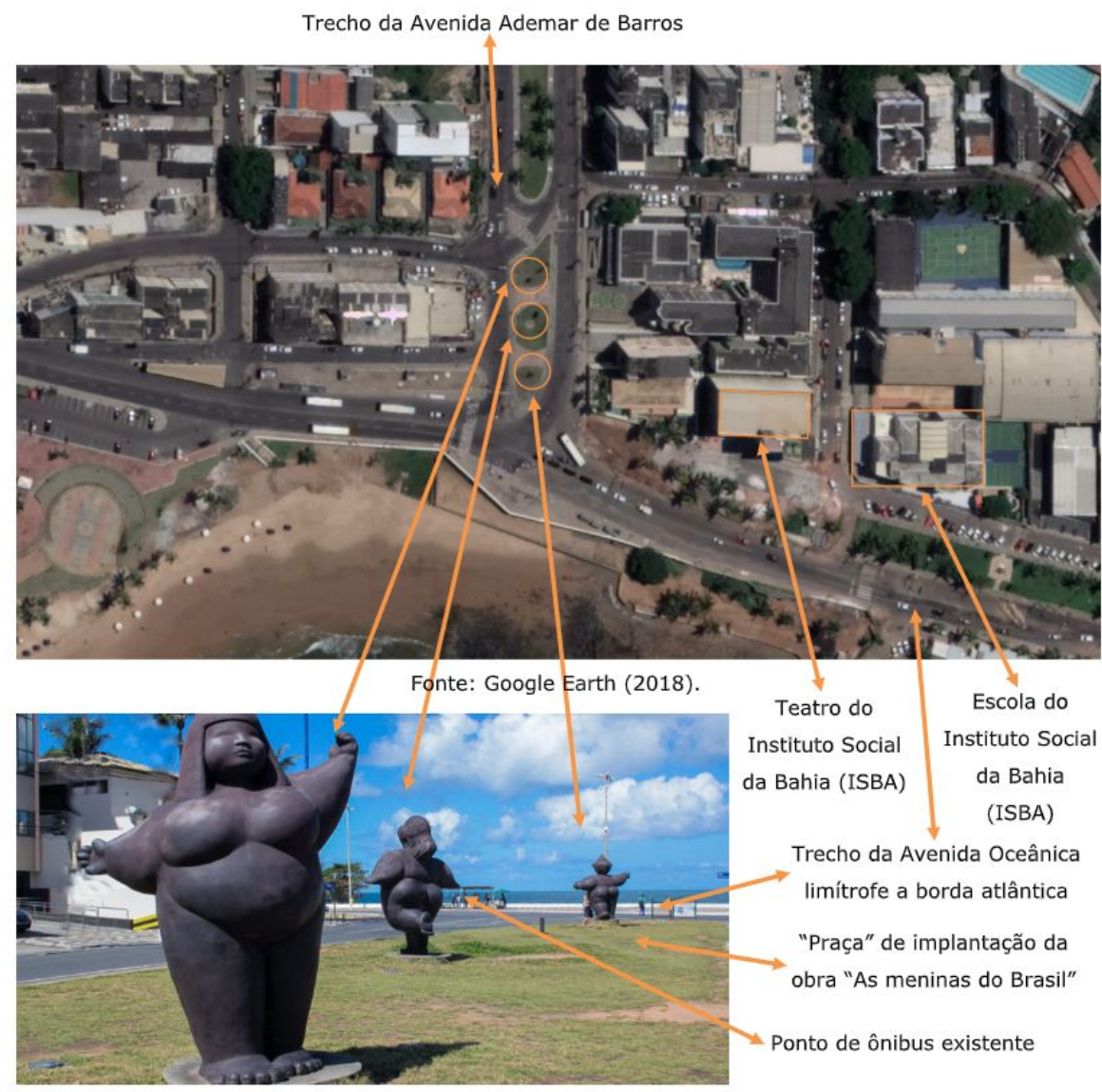

Fonte: Antônio Queiroz (2019).

Figura 02: Esquema visual indicando a vizinhança o local de implantação da escultura "As meninas do Brasil" com destaque para algumas vias e equipamentos urbanos de importância na localidade. Acima imagem via satélite e abaixo foto da obra.

Fonte: Elaborado pelos autores (2019). 


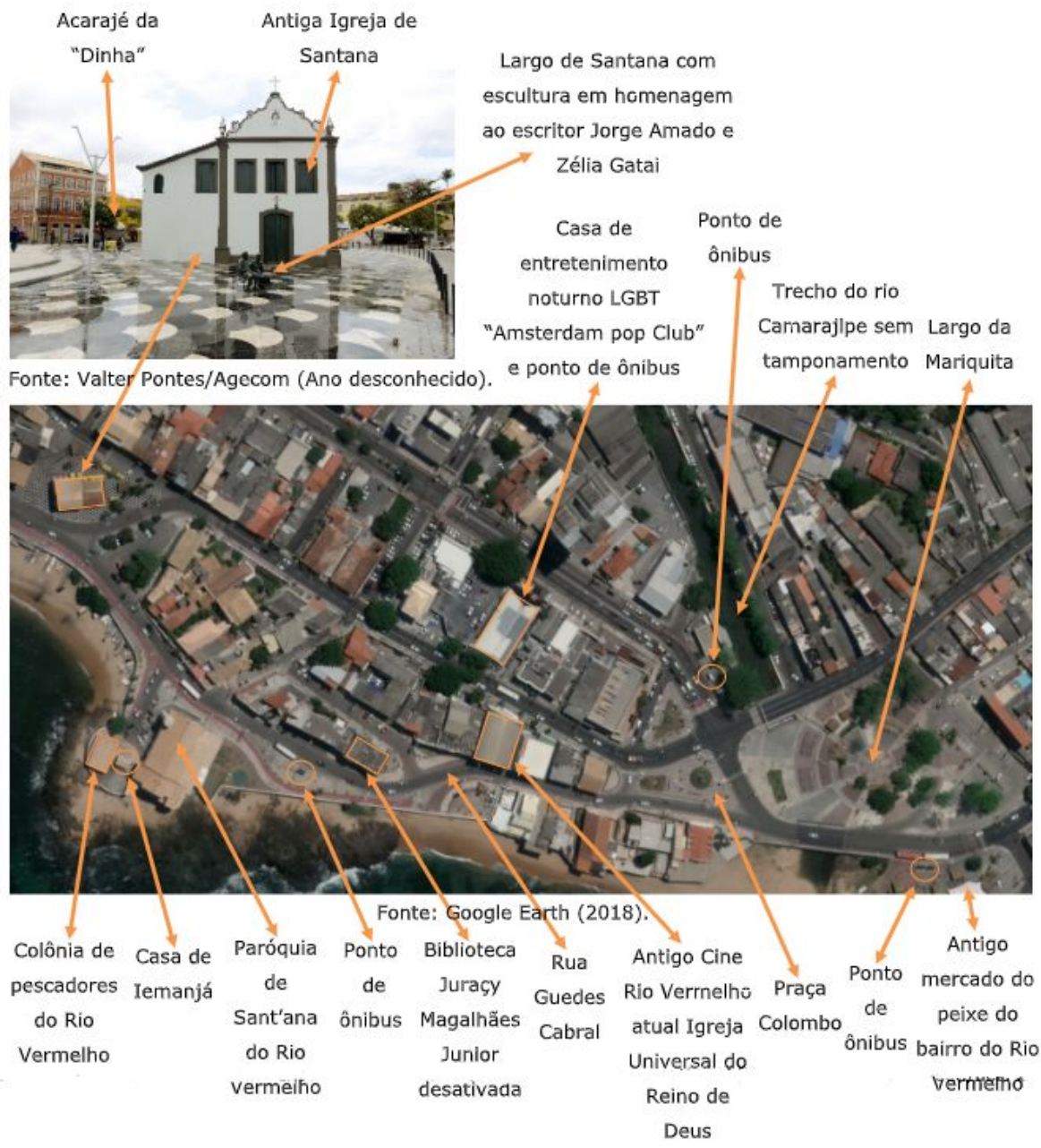

Figura 03: Esquema visual indicando o trecho "Santana-Mariquita" com destaque para algumas vias e equipamentos urbanos de importância na localidade. Acima imagem via satélite e abaixo fotos do trecho. Fonte: Elaborado pelos autores (2019).

A escolha de uma área de interesse cultural entre os dois largos (Santana e Mariquita) dá-se pela natureza da poligonal, onde a sensação que se tem é de que um espaço convida de forma intrínseca a visitar o outro estabelecendo uma relação de vizinhança, algo comprovado durante 0 levantamento iconográfico/historiográfico e na etapa seguinte onde prosseguimos com observações em campo.

Durante a realização dessas visitas e utilizando um recorte temporal correspondente entre os meses de julho e dezembro de 2019, período entre a escrita inicial e revisão desse artigo, os 
membros do grupo de pesquisa reservaram um turno do seu dia para observarem a relação que os transeuntes estabelecem com a obra de arte, nem que seja uma pausa para observação descompromissada ou para tirar uma foto. A intenção aqui é perceber se as obras são vistas como elemento de permanência, ou seja, se as temporalidades que os sujeitos constroem no espaço, possibilitam a elevação do mesmo à categoria de lugar.

Tendo o resultado da observação descrito, partimos para a terceira etapa: a compreensão das relações construídas com as obras de arte inseridas no contexto histórico-social-econômico-cultural ao qual elas se encontram, trazendo os conflitos e contradições do campo para um plano teórico analítico. Tais construções conceituais se fazem fundamentais para leitura desses espaços enquanto possíveis obras de arte.

Sendo assim, elencamos uma base de autores que assim como o espaço é multidisciplinar, o que torna a escolha de Santos (1996) e Argan (1992) na bibliografia, um elemento básico. Também são analisados e reunidos de modo complementar os conceitos de imagem vide Lynch (1997), patrimônio vide Santos (1986) e Canclini (1994), memória vide Pollack (1989) entre outros autores apresentados mais à frente para compreender as disputas tanto do ponto de vista material quanto imaterial que incidem no espaço.

Nesse momento de viés conceitual, apropriamo-nos de instrumentos metodológicos originários do campo antropológico, associados a uma compreensão dialética da relação entre sujeito, cidade e arte, com a finalidade de proporcionar possibilidades de relações conceituais amplas que são determinantes à conclusão aqui almejada.

É na complementaridade e consequentemente na retirada de tensão analítica entre os diversos autores que se debruçam sobre o espaço urbano bem como as problemáticas culturais nele inseridas, que talvez possamos caminhar para a construção da quinta e última etapa, o de tentar repensar o papel da arte no meio urbano. Como 
afirmava Baudry (2008) em O pornô como experiência urbana, o jogo com a imagem é fundamentalmente urbano, resta-nos pesquisar e experimentar os jogos imagéticos que ainda encontram-se silenciados na alteridade, denunciar quais os sujeitos que ainda sequer foram convidados para jogar, suas trajetórias, desejos e consequentemente suas apropriações na urbe.

\section{Desenvolvimento}

\subsection{O capital de troca como solvente da obra de arte - A obra "A} Mãe Baiana" do artista Carybé implantada em frente ao shopping da Bahia

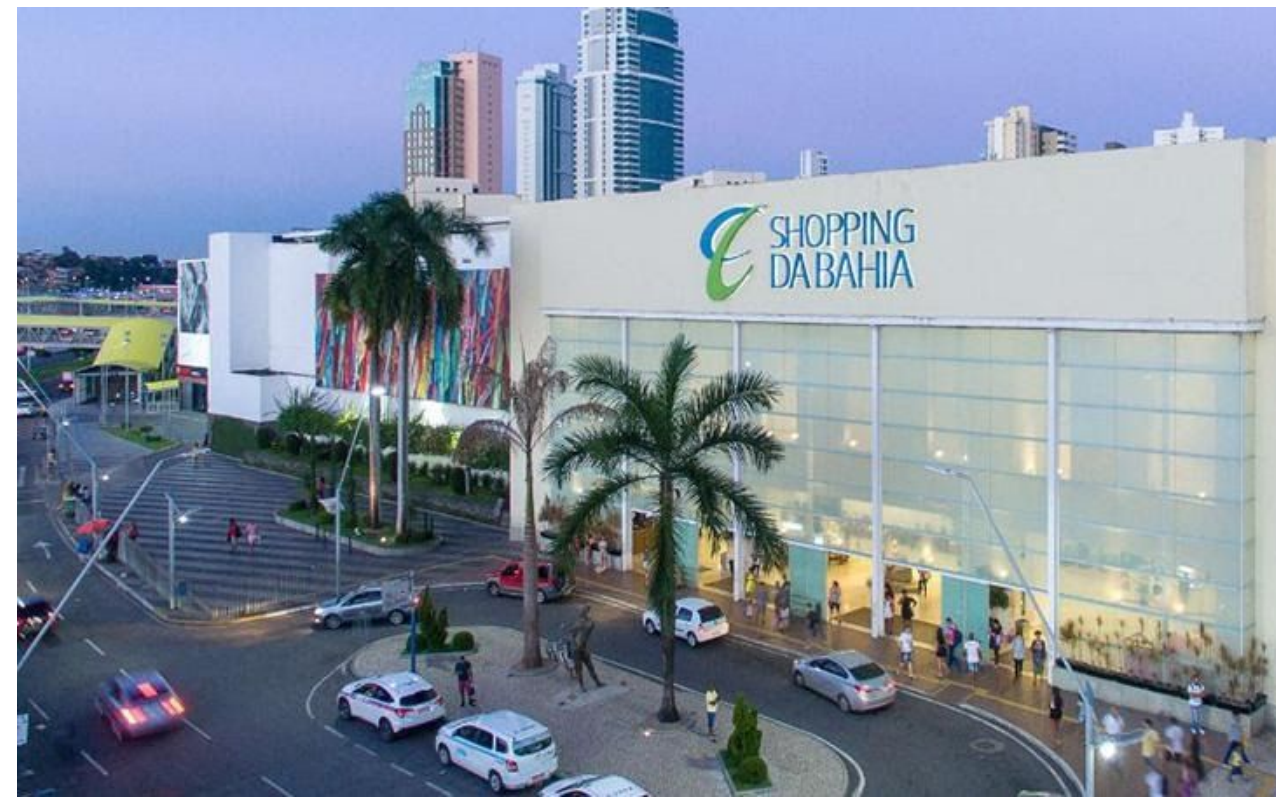

Figura 04: Foto da fachada principal do shopping da Bahia, localizado na Avenida Tancredo Neves, Pituba, Salvador-Ba.

Fonte: Elaborado pelos autores (2019).

Antes de começarmos o nosso exercício é interessante levantar a seguinte questão: ao analisar a figura 04 sem qualquer noção de conhecimento da obra "A mãe Baiana" de Carybé você seria capaz de identifica-la na fotografia? Se sim, nossos parabéns contudo, caso não tenha a identificado de imediato, nossos parabéns 
igualmente, alguns de nós que estão escrevendo esse texto não foi capaz de vê-la e desse debate surgiu o presente texto.

A obra Homenagem "A Mãe Baiana" de autoria do Artista Carybé, feita de bronze patinado e com seus três metros e trinta centímetros de altura encontra-se situada em frente ao antigo Shopping Iguatemi (atual Shopping da Bahia). Trata-se de uma obra privada encomendada pela própria administração do Shopping.

No que tange ao papel de sua implantação num pulsante centro comercial que viria a nascer em meados da década de 1960 com o primeiro grande shopping center da cidade (Vide figura 05), a mensagem subliminar proposta era a de acolhimento, daí a construção de uma imagem posta na figura da relação maternal, tendo em vista que este é o primeiro elo do sujeito com o mundo. A intencionalidade está clara e vem transmitir um sentimento "tipicamente Baiano", a forma de mulher carregando o seu filho no colo vem não somente para recepcionar os clientes mas, para agregar valor econômico reforçado por um prestígio simbólico de se estar consumindo num shopping onde existe uma bela recepção com uma bela obra de arte de um artista famoso. Posto isso, podemos afirmar que este gesto tem de forma sutil o objetivo de ser apropriado pelo sujeito como elemento apaziguador da exploração do máximo de capital econômico ali existente. 


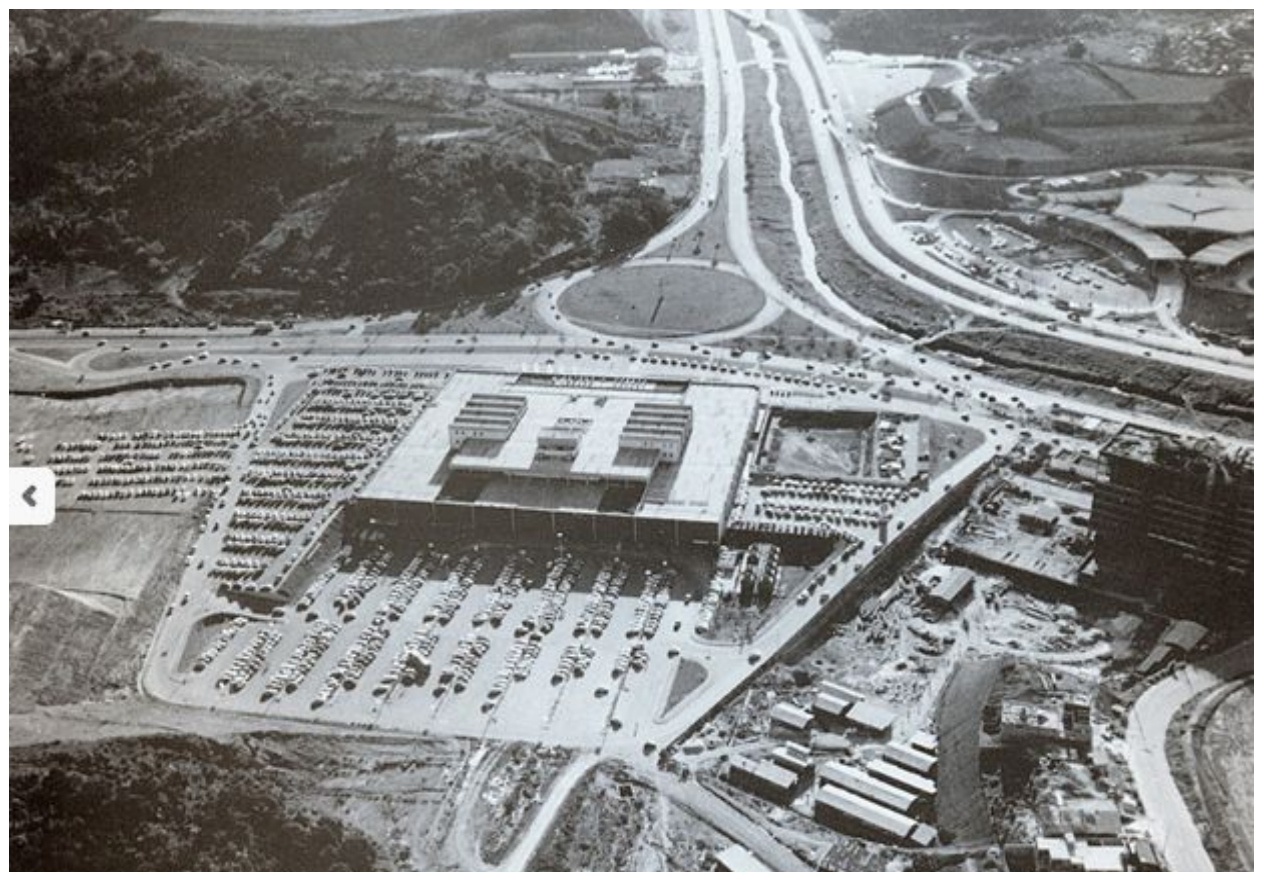

Figura 05: Vista superior do entorno do "Shopping Iguatemi" durante à 1970.

Fonte: http://www.amoahistoriadesalvador.com/page/7/. Acesso em 19 ago.2019.

Sendo assim o que resta da obra de arte? Ela conseguiria reorganizar o modo de apropriação do espaço? Nem uma mera referência para o encontro ela é capaz de ser. Quem está nas mediações da "Mãe" está para fazer algo, ou seja, a dinâmica existente naquele local não propicia a visibilidade da obra por parte do sujeito não só do ponto de vista físico (como iremos abordar mais à frente) mas, pelo fato de não permitir ao próprio sujeito perceber-se e ser percebido para além do capital econômico, comprometendo qualquer modo de contemplação quer seja artística numa reflexão moderna (de afastamento entre sujeito e objeto), quer seja contemporânea (onde arte e sujeito se misturam). Existe, pois, uma desapropriação de qualquer modo de sentir o espaço daí o esvaziamento de sentido da própria obra e do sujeito, uma vez que, sua condição existencial dá-se pela via do consumo e do desejo bombardeado a todo momento de forma inerente num caos que não o convida ao encontro, mas ao anonimato. 
O cenário da obra ganhou diversas modificações que influenciaram em sua visibilidade. Se no ano de sua implantação em 1984 poucos eram os carros que circulavam na região (vide figura 06) dificilmente se pensava na intensa concentração do comércio informal que encontramos atualmente onde, os sujeitos históricos contemporâneos trabalhadores em sua maioria pretos e periféricos na correria do dia-a-dia pouco se preocupam se estão sendo recebidos de maneira afetuosa ou não, as necessidades são outras com a crescente taxa de desemprego do país e o afeto dista das relações econômicas que constituem a identidade do lugar e a obra contínua não sendo vista!

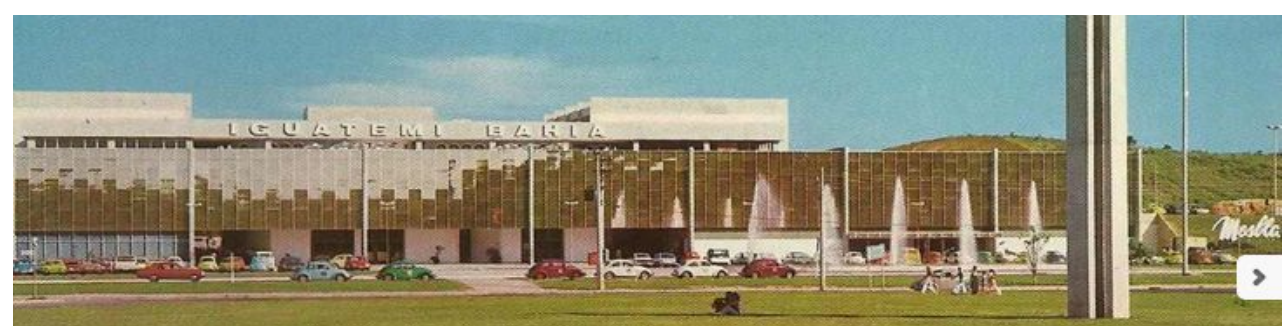

Figura 06: Fachada principal do antigo Shopping "Iguatemi" atual Shopping da Bahia em 1976. Fonte: http://www.amoahistoriadesalvador.com/page/7/. Acesso em 19 ago.2019.

Contudo é somente do ponto de vista simbólico que a obra não é legível ou o resultado dessa relação simbólica acaba deixando os rastros de suas contradições materialmente? Desse modo Lynch (1997) em "A imagem da cidade" acaba por nos fazer pensar um pouco em nossas realidades, mesmo escrevendo sobre tão longe em Boston, Nova York e Los Angeles, ao conceituar alguns dos elementos que compõe a leitura imagética urbana (a lembrar: Vias, Limites, Bairros, Pontos nodais \& Marcos), o autor destaca a possibilidade dos mesmos serem flexíveis principalmente em função do recorte de escala:

A imagem de uma dada realidade fisíca pode ás vezes mudar de tipo conforme as diferentes circunstâncias do modo de ver. Assim, uma via expressa pode ser um canal de circulação para o motorista e um limite para o pedestre. Do mesmo modo, uma área central pode ser um bairro, quando uma cidade é 
organizada em escala média, e um ponto nodal, quando se leva em conta toda a área metropolitana. Mas as categorias parecer ter establidade para um determinado observador quando ele opera num determinado nível. (LYNCH, 1997, p.54)

Sendo assim, partindo de uma análise de escala começando pela física e tendo como referencial o ser humano, o fato da obra estar implantada num ponto nodal, sendo assim perto de convergências de vias, de fluxo de veículos e modais de transporte, enfim, condensações em virtude do uso e do tipo de ocupação do solo predominante comercial, se tem como resultado a ausência de permanência das pessoas e o trânsito contínuo assumindo, pois, uma temporalidade característica pensamento semelhante ao analisarmos a análise simbólica.

Existem limites também. Só para lembrar, os limites conceitualmente podem ser:" [...] barreiras mais ou menos penetráveis que separaram uma região da outra, mas também podem ser costuras, linhas ao longo dos quais duas regiões se relacionam e se encontram" (LYNCH, 1997, p.52). Durante a visita de campo ao sítio onde a obra está implantada, percebemos essas "barreiras" que na escala humana dificultam a possibilidade de contemplação, para isso escolhemos três pontos os quais achamos interessantes para divulgar essas dificuldades.

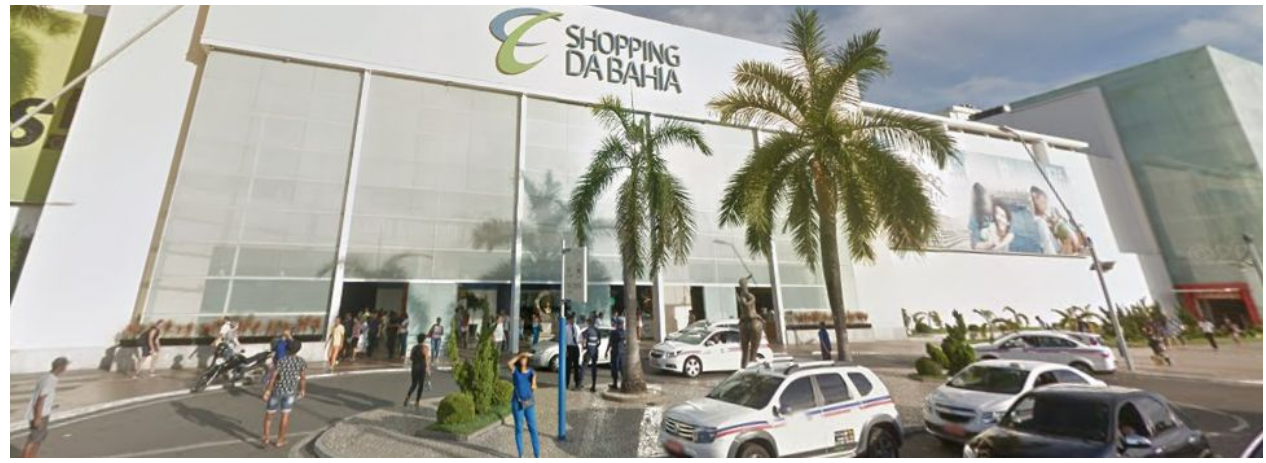

Figura 07: Foto da fachada principal do shopping da Bahia, localizado na Avenida Tancredo Neves, Pituba, Salvador-Ba, com destaque para o canteiro central e rotatória.Fonte:https://varelanoticias.com.br/shoppings-de-salvador-abrem-mais-cedo-nestablack-fridaY. Acesso em 14 jan.2020. 
A primeira, e como podemos ver na figura 07, é que a obra se encontra num canteiro circundado por uma via de acesso temporário para veículos (prioritariamente táxis, carros de aplicativo e de passeio e em casos mais graves ambulâncias), ou seja, caso alguém deseje tecer relações mais próximo da obra, o primeiro obstáculo é atravessar duas faixas que, por serem em frente ao acesso principal de pedestre do shopping, vivem movimentadas, elas são a costura de quem vem da Avenida Antônio Carlos Magalhães e de quem vai para buscar alguém ou estacionar no shopping.

A segunda barreira caso a pessoa não opte por atravessar as faixas, lhe sobra a opção de contemplar próximo a uma das portas de acesso ao primeiro andar do shopping, a melhor visibilidade sem obstrução de motos e carros na altura da vista do observador. Contudo, não podemos esquecer do comprometimento da circulação criando assim então uma barreira variável de acordo com o horário e o fluxo de pessoas. Algo semelhante acontece também, em frente ao shopping, atravessando as faixas próximo ao ponto de ônibus, a passagem das pessoas num fluxo contínuo de saída e chegada dos ônibus constroem a barreira visual que impede a permanência e visibilidade da obra tal como o trânsito de carros, motos e caminhões que naquela avenida passam conforme podemos observar na figura 08. 


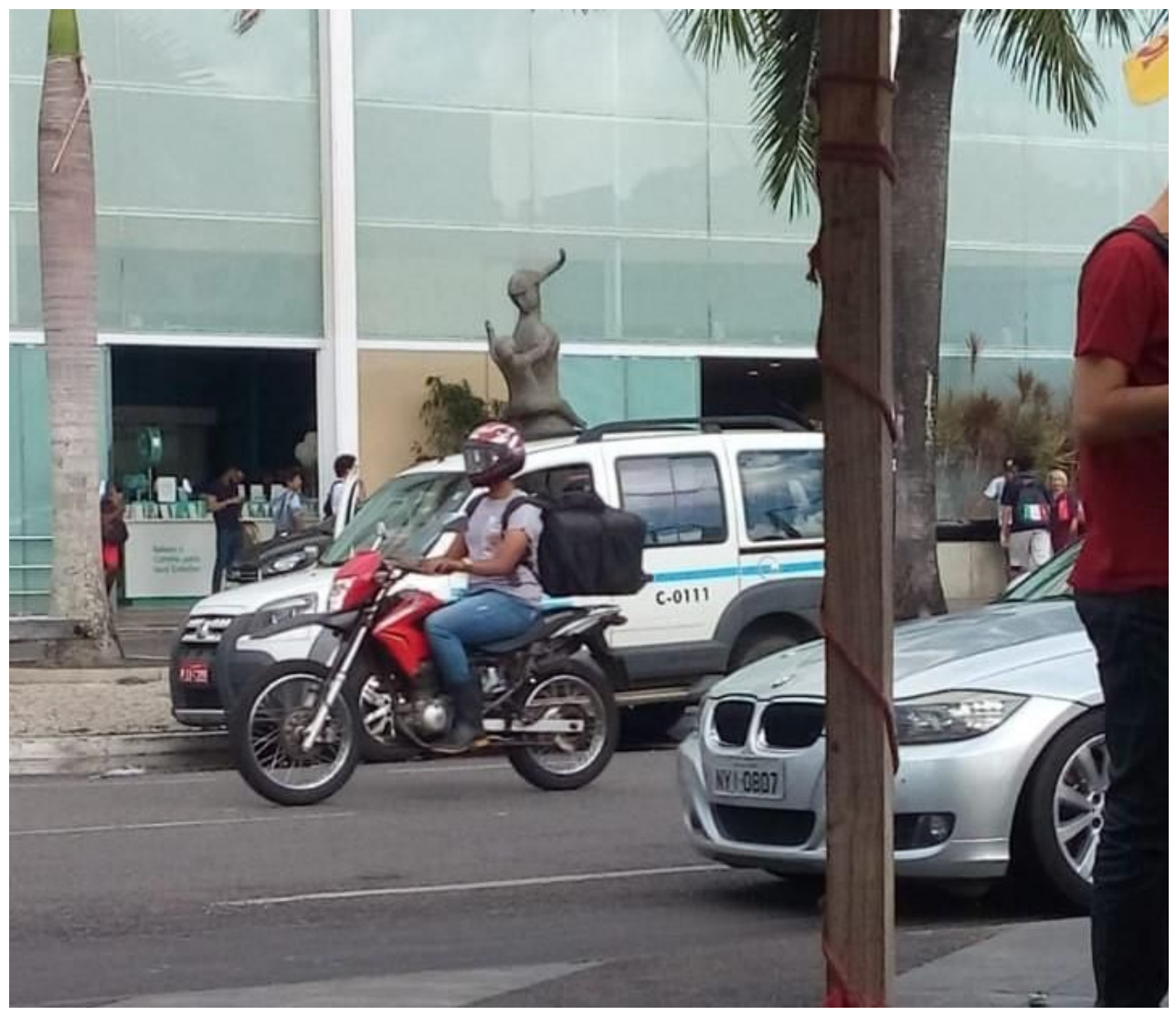

Figura 08: “A mãe Baiana” entre os carros e motos da Avenida Tancredo Neves. Fonte: Acervo dos autores (2019).

Compreendendo, pois, que a obra se encontra num ponto nodal de centralidade comercial e elucidando os "limites" e as "barreiras" resta-nos agora para concluir essa leitura física da paisagem na qual encontramos a solitária "mãe" fazer uma análise dos "marcos". Os marcos conceitualmente são os elementos físicos que agregam identidade espacial tornando-se mais fáceis identifica-los quando possuem: "[...] uma forma clara, isto é, se contrastam com seu plano de fundo e se existe alguma proeminência em termos de sua localização espacial" (LYNCH, 1997, p.88).

Feita a análise podemos afirmar que a obra não consegue em si mesma, reorganizar o modo de apropriação de espaço. Nem mesmo colocar-se como mera referência para o encontro, seja ela de qualquer natureza uma vez que, o espaço ali não é apropriado pelo 
sujeito, impossibilitando o mesmo de ressignificá-lo. O valor econômico das relações com o espaço abafa qualquer outro modo de percepção que não seja este.

A obra de Carybé, por infortúnio do destino ou não, se encontra rodeada de marcos sendo os mais antigos o próprio shopping da Bahia junto a estação rodoviária de Salvador já mencionados. A própria "mãe" seria para Lynch igualmente um marco, contudo precisaríamos encarar a paisagem urbana como um texto onde alguns conceitos são mais claros e inteligíveis e outros exigiriam uma "experiência" contínua do leitor.

Isso se dá, pelo fato da a obra não ter sido pensada historicamente como um elemento complementar que fizesse da fachada principal do shopping Iguatemi o seu plano de fundo ou até mesmo de maior monumentalidade e destaque. Longe disso, ela surge como elemento de adorno, retificação de um padrão urbanístico, uma nota de rodapé que, auxiliada de outro elementos urbanísticos potencializam a consolidação do shopping enquanto equipamento urbano de relevância e a administração do shopping traduz isso, ou seja parafraseando o Walter Benjamim a arte aqui é fruto e tem como por objetivo a reprodutibilidade técnica tal como vemos em Argan. Sendo assim, por mais ingênuos que fossemos acreditar que existe uma modificação da paisagem com a implantação da obra é superestimar demais o papel do artista que eu seu cerne não tem interesse em romper com o status quo.

Contudo, devemos questionar o que é esperado da arte de modo geral; a arte tem diversas funções, mas poderíamos citar que uma delas é como dissipadora do $\operatorname{caos}^{3}$. A cidade possui diversas faces, cada espaço expressa uma característica, que não necessariamente tem equivalências, sendo assim podemos afirmar que o caos é próprio do modo de acontecer do urbano. E sendo, como afirma Fischer, a função da arte é a reorientação do caos à medida que determina uma nova origem na compreensão da vida,

\footnotetext{
${ }^{3}$ Ver FISHER (1967),
} 
observamos que a "Mãe" não consegue cumprir essa função. Sendo assim, questionamos por que isso ocorre, se a obra acontece em seus valores estéticos, técnicos e espaciais? A aparente desordem contida no cenário da obra é tão dinâmica, constante e absoluta que consegue dominar o espaço por inteiro, impossibilitando qualquer sentido de ordem, mesmo da obra ou ainda, do sujeito.

Daí a importância da combinarmos a análise tanto física da manifestação artística material quanto do ponto de vista conceitual, não existem aqui (nesse recorte empírico em específico) contrariedades, mas, a possibilidade de tecer complementariedades que expõem o quão perversa pode ser a ação do capital, legitimando sua exploração e resguardando-se na arte.

Para uma reorganização do espaço que o possibilite revelar a sua natureza epistemológica de obra de arte, para além dos equipamentos urbanos e objetos que podem iniciar um olhar sob a escultura por exemplo, é necessário uma alteração, que diminui expressivamente o fluxo contínuo de pessoas, que modifique a dinâmica econômica do local e ressignifique o sentir do tempo, isso porque, para poder ver um objeto urbano é preciso não olhar somente a obra mas, subtrair o que não nos permite vê-la, e isso vale tanto na equivalência entre cidade e arte, como na construção da ideia do objeto de arte como caminho deste conceito.

\subsection{A ausência do capital de troca e simbólico - A obra "Meninas do Brasil" implantada no Bairro de Ondina}

Se a obra "A mãe Baiana" elucida que a temporalidade existente na localidade de implantação não permite que o sujeito se perceba e nem perceba a escultura, visto que a relação de tempo se baseia na troca e não na permanência prolongada das pessoas. Ao analisar um cenário oposto, dotado de menos "marcos", "limites" e "barreiras" podemos afirmar que uma manifestação artística por si mesma poderia materialmente ressignificar o espaço e a percepção dos sujeitos que ali moram ou passam? Está é, pois, a questão que 

possibilidades.

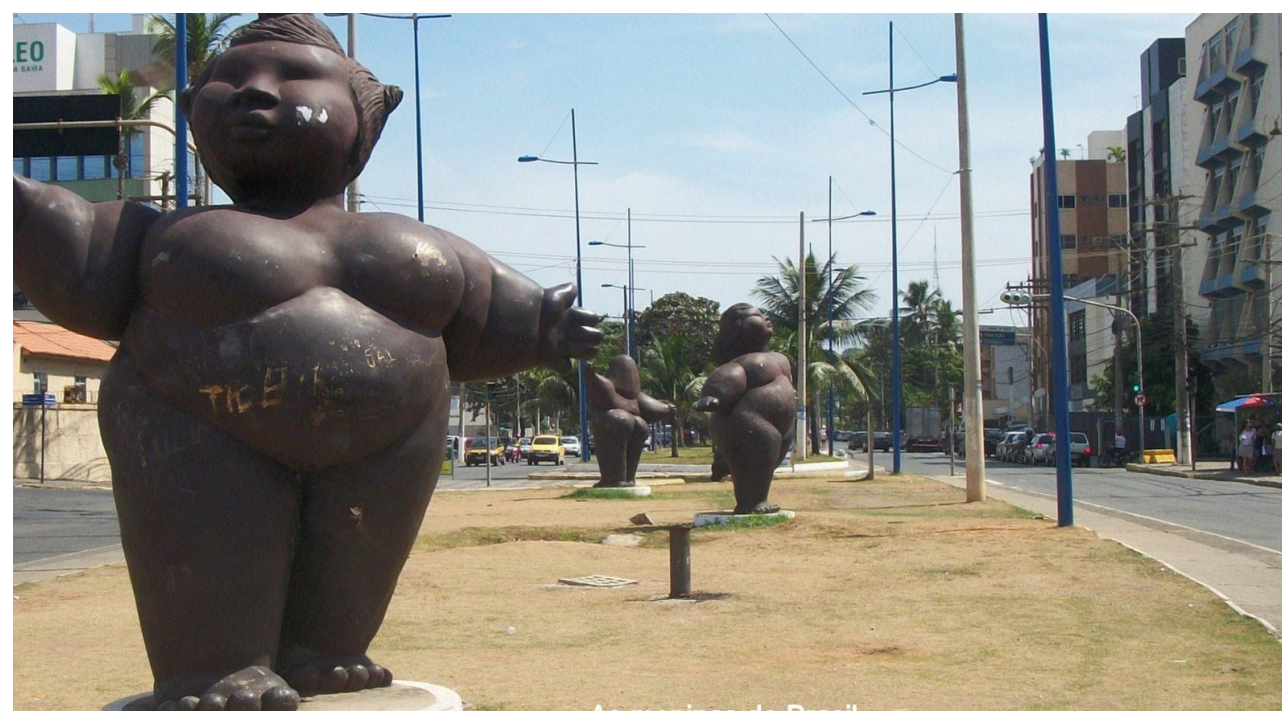

Figura 09: Fotos da obra "Meninas do Brasil" da escultora Eliana Kertész.

Fonte: http://dechiricoarteseartistas.blogspot.com/2011/03/blog-post.html. Acesso em 14 jan.2014.

"As meninas do Brasil", conjunto monumental popularmente conhecido como "As Gordinhas de Ondina", é formado por três esculturas de mulheres gordas e nuas, localizadas na praça Eliana Kertész já no trecho final da Avenida Ademar de Barros, importante ponto nodal do bairro de Ondina. Composta de três mulheres de nome Mariana, Damiana e Catarina são inseridas numa paisagem tipicamente costeira sendo o mar talvez o grande "limite" se levarmos em consideração a escala humana. Na concepção da artista a obra representa:

“[..] a origem da gente, o branco, o negro e o índio. E cada uma voltada para um lugar. Uma voltada para a África, a negra, a branca, voltada para a Europa e a índia voltada para o interior, para as matas" (KERTÉSZ, 2014).

Ainda que, a resolução das formas não expresse a origem étnica, as posições espaciais diferenciadas, para sua terra de origem, 
o fazem, ou ao menos tentam fazer, isso porque não comunicam estes conceitos. As obras feitas de bronze e pesando cerca de uma tonelada, chamam mais a atenção de quem passa pela avenida, não só devido as suas formas arredondadas, curvas e de volumetria, mas, pela quase ausência de elementos, concretos ou não, que preenchem o seu entorno.

Não existem muitos elementos de obstrução da leitura da obra, tirando o fato de que a mesma tal como a obra de Carybé fica situada dentro de um canteiro entre duas vias, aqui no caso arteriais. O acesso a quem deseja ter um contato mais próximo é dado através da faixa de pedestre existente junto ao único ponto de ônibus do local (o outro no momento encontra-se desativado devido as obras de pavimentação urbana na orla) que funciona igualmente com "marco" paralelo as esculturas das três mulheres, destacando-se do plano de fundo com sua volumetria avantajada.

Ou seja, o entorno no qual as obras estão inseridas, favorece a sua notoriedade no espaço, considerando que estão assentadas numa praça vazia com objetos públicos em destaque e não encontramos outros mobiliários urbanos de grande porte ao redor, que ao menos, possibilitem a compreensão do espaço enquanto praça - lugar preenchido de história e sentido. De outro modo, a presença das vias arteriais, do ponto de ônibus próximo, da dinâmica de serviços e equipamentos urbanos, tais como, clínicas médicas, colégios, a Universidade Federal da Bahia (UFBA) entre outros, possibilitam que mais pessoas tenham contato, percebam a obra, transitem pelo local. Um outro fator que ratifica a percepção é a restrição de grandes gabaritos pela Lei de Ordenamento do Uso e Ocupação do Solo de Salvador (LOUOS), perto da orla, o que evidencia mais ainda a antropometria e volumetria do conjunto escultural, permitindo sua visibilidade.

As estatuetas foram implantadas no espaço público de Ondina, em 2004, tendo em vista que a Prefeitura de Salvador, na administração do prefeito Antônio Imbassahy, realizou uma 
solicitação à artista encomendando à obra. Com efeito, "As Gordinhas" remontam um advento importante a apropriação do conceito de arte contemporânea - o fim dos espaços institucionalizados e idealizados para as exposições artísticas, como os museus e galerias, característicos da arte moderna. A incorporação da arte nos espaços públicos, e a cidade como galeria urbana possibilita que esta cumpra um papel para além da estética/técnica pois, ao aproximar o objeto de arte do sujeito, constitui-se uma função política e social. Assim, quando o objeto de arte é imerso no espaço urbano, em contato com os transeuntes e com a vida cotidiana, dos acontecimentos históricos e tensões sociais, culturais, estéticas e políticas, constitui-se uma relação entre o sujeito e a obra, que em última instância permite o próprio conceito de arte.

Deste modo, as galerias são substituídas pelas ruas, praças e muros. Podendo a céu aberto, as obras serem contempladas e vivenciadas pelos citadinos. Para Argan (1992, p.224) as práticas visuais inscrevem-se de alguma forma, no campo de urbanismo, visto que: "[...] faz urbanismo o escultor, faz urbanismo o pintor, faz urbanismo até mesmo quem compõem uma página tipográfica [...]", porque a cidade é a própria obra. Ou seja, as Gordinhas são obras dentro de uma obra maior que é a cidade, e o artista passa a ser um dos produtores deste objeto assim, o que pretendemos aqui é analisar como a obra menor faz ressignificar a obra maior, e se não o faz porque não o faz. Mas, ainda assim a resolução das formas da escultura não ser capaz de suscitar um diálogo estético-racial consistente à medida que o elemento escolhido pela autora para diferenciar as três mulheres (por inocência ou reprodução de um racismo estruturante) é o cabelo, um demarcador potente, mas igualmente problemático se pensarmos na delimitação estética no trato dos corpos.

As posições espaciais "estrategicamente voltadas" para sua terra de origem não dão conta da dimensionalidade do que é ancestralidade enquanto conceito e da memória socialmente 
construída em torno do passado inclusive porque as mesmas estão inseridas numa "praça" ausente de mobiliário urbano que possibilite a apropriação do espaço.

Mesmo sendo "As meninas do Brasil" capturadas e ressignificadas pelo sujeito, que se apropria da nova compreensão de objetos de arte, a narrativa da artista é desconstruindo à medida que substituem a diversidade étnica se concentrando na representação de corpos femininos distantes dos padrões estéticos convencionais da magreza, abre portas para o engajamento social da arte que na sua lógica subjetiva dista do conceito/intensão do objeto em si, e é apropriada não a partir da identidade étnica de formação do povo brasileiro, mas na perversão da estética corporal.

As estatuetas se caracterizam como obras site-oriented, isto é, obras que se encontram em espaços não institucionalizados e cuja dimensão sociocultural prevalece. No caso das "Gordinhas", configuram uma desconstrução do modelo corpóreo idealizado pela mídia e pela sociedade. Outro fator que causa impacto nas esculturas monumentais diz respeito a nudez das mesmas, o corpo é capturado no imaginário das pessoas que visitam ou transitam cotidianamente pelo local à medida que, a nova proposta estética apresentada pela autora nos induz a encontrar beleza num corpo que não é magro, e sim sinuoso, volumoso e que está nu, nos direcionando a uma dimensão mais ampla e liberta do corpo padrão da mulher por outro lado, a proposta corporal esvazia a possibilidade de construção e identificação de etnias, logo o que temos é o vazio conceitual que impossibilita uma nova construção identitária como já falamos.

Sendo posta deste vazio espacial - a frente o mar e a avenida de orla, nas laterais, vias largas de acesso local, no entorno o pouco denso comércio, as esculturas se transformaram numa referência espacial do bairro de Ondina, ou seja, o espaço passa a ter uma nova referência a partir da leitura do corpo, visto que é conhecido como "As Gordinhas". Dessa maneira, levando em consideração a arte como elemento de identificação espacial, as obras de arte de Kertész 
passam a identificar o bairro Ondina (vide figura 10), que antes da implantação das "Moças Gordinhas" não possuíam nenhum elemento identitária, nem de destaque em relação aos outros bairros. Ondina era o caminho entre dois bairros - Barra e Rio vermelho, de grande densidade, já referendados da orla de Salvador.

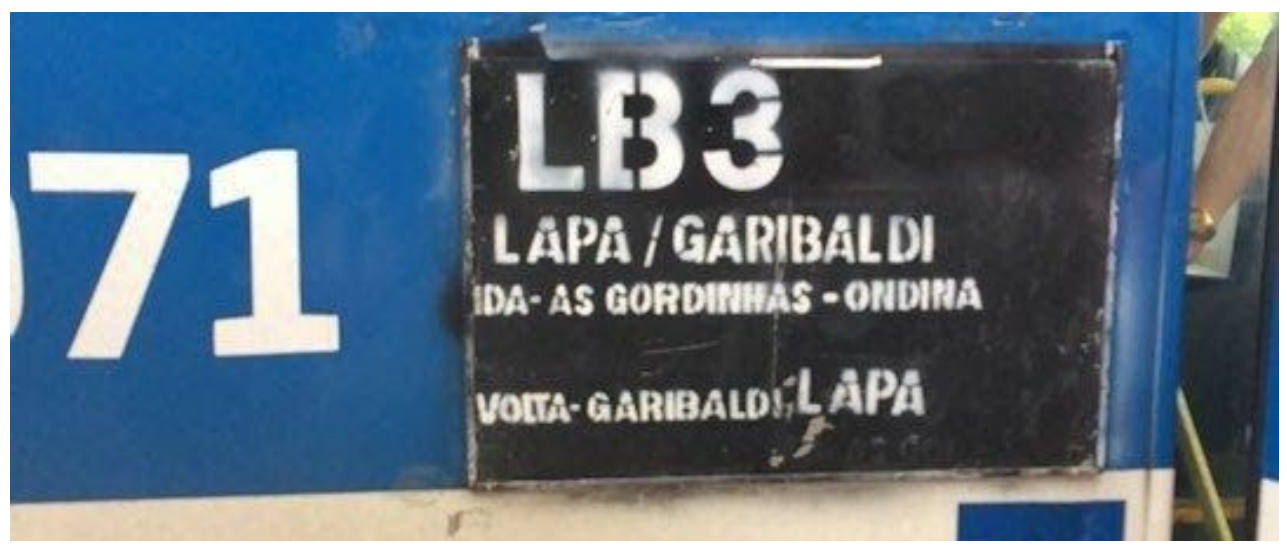

Figura 10: Roteiro da linha "Lapa-Garibaldi" com destaque para a utilização das "Gordinhas" como referencial de trajeto.

Fonte:https://www.metro1.com.br/noticias/cultura/84123,as-gordinhas-de-eliana-kert esz-comemoram-15-anos-nesta-quarta. Acesso em 14 jan.2019.

Tal vazio espacial permite a apropriação do espaço pela obra, e esta trouxe uma nova identificação, todavia, a obra não é capaz de ressignificá-lo, pois o entorno não favorece para além da referência espacial. Um aspecto que vale ser citado, é em relação ao local onde estão assentadas as estatuetas ser denominado de praça, sendo que, se tais elementos fossem implementados, a praça seria algo possível de ser vivido pelo sujeito, teríamos necessariamente espaço de relações, possivelmente um lugar de encontro, de permanência, de afetividade. Diante do vazio espacial deixado pela "praça" a obra passa a ser uma referência unicamente geográfica.

No entanto, o caráter transformador do objeto só se dá pela relação do sujeito no espaço-lugar, e no caso das "Gordinhas", apesar de se ter uma interação com o sujeito devido a leitura do corpo, tal interação não é suficiente para ressignificar o espaço enquanto lugar, e portanto fazer emergir a sua natureza de obra de arte. Porque que 
as esculturas o compõem esteticamente, onde as pessoas apenas transitam por ali, mas não permanecem, não há relação completa entre o sujeito, a obra e o espaço, logo não ressignificam, apenas o georreferenciam.

Contudo, a função da obra de arte não é pontuar o espaço de modo a georeferenciar-lo, é antes e prioritariamente dar início, permitir, possibilitar o sujeito de perceber não só a obra, mas o objeto no qual ela está contida. Ou seja, um caminho possível para a percepção da cidade enquanto objeto de arte, logo enquanto lugar, a interação entre o sujeito e a obra, permite o nascedouro do sentimento de pertencimento. Tal sentimento, garante e se confirma à medida que o espaço ganha dimensão de memória.

Para Pollak (1989), a memória necessita de um elemento concreto, possível de ser revisitado, por tanto capaz de dialogar com o sujeito, e sendo assim dotado de significados. O que o vazio desta praça não possibilita, visto que não tem somente a forma concreta posta na ausência de mobiliários, mas antes no próprio vazio da ideia, que se constrói com base na vida cotidiana. Assim, “As Meninas do Brasil" ou "As Gordinhas", trazem em si, em última instância o mesmo vazio do espaço que ocupam, pois tendo nascido de um conceito, relacionam-se com o sujeito sendo outro, bem distante do pretendido, permanecendo suspensas, à medida que denominam, referenciam, identificam, mas não constroem uma relação de lugar neste espaço, que permanece como "terra de ninguém" entre dois lugares.

\subsection{O capital cultural como solvente da obra de arte na cidade - A poligonal entre o Largo de Santana - Mariquita, localizada no Rio Vermelho.}

Conforme explicitado anteriormente, um monumento artístico pontual inserido no espaço urbano e de forma externa ao sujeito, não é capaz por si só de promover novos usos ao lugar em questão tão quanto, de promover novos vínculos identitários e 
afetivos. O meio externo a obra de arte influi diretamente em como se relacionar com a mesma de modo que, se caso da obra Mãe, a dimensão do capital material dinâmico sobressai a qualquer possibilidade de contemplação, às "Meninas do Brasil", apresentam o oposto, fazendo-nos enxergar a obra de maneira cristalizada e estática, tal como uma pedra, sendo um referencial de posicionamento.

No entanto, e se considerarmos ao invés de um espaço onde a relação cultural não é a preponderante e sim, um no qual ela é égide de sustentação das relações? A obra de arte inserida nesses "ateliês urbanos" poderia de fato, convidar os sujeitos a se relacionarem, e se identificarem com uma porção da cidade? O objetivo desse tópico é evidenciar se essa condição seja verdadeira e caso não, quais as produções espaciais que impedem essa relação entre sujeito, cidade e obra de arte. Por isso, escolhemos como lugar de análise o bairro do Rio Vermelho, especificamente o percurso entre o Largo de Santana e o da Mariquita (vide figura 11), não somente por serem os mais visitados, mas, por estarem relacionados historicamente com a cidade de Salvador, em especial pela comunidade pesqueira remanescente de expressividade religiosa. Foram feitos alguns levantamentos iconográficos entre o período de 1970 e 2019, traçando uma retrospectiva de uso e ocupação do solo como forma de compreensão das manifestações artísticas e sua respectiva intencionalidade. 


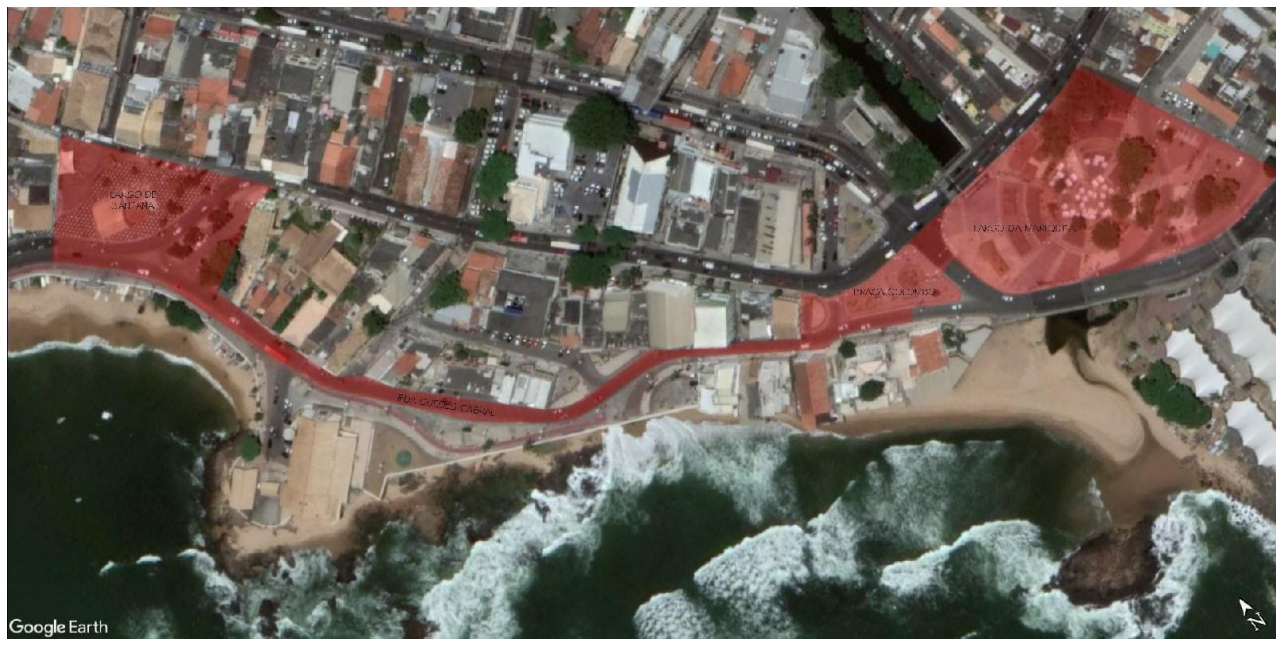

Figura 11: Mapa com demarcação da poligonal estudada do trecho Largo de Santana-Mariquita destacada na cor vermelha.

Fonte: Google Earth (2019).

Conforme elucidado na matéria de tom irônico do Jornal da Bahia em 1991 "Caramuru não deu Chabu", o histórico da localidade do Rio Vermelho, confunde-se com a própria inauguração de Salvador uma vez que no lugar onde encontra-se o atual Largo da Mariquita:

“(...) existira (sic) uma antiga aldeia Indígena chamada "Maraquiqui" (que é uma corruptela do vocábulo Tupi e significa 'onde chega/param os brancos. [...] Com o passar dos anos, a aldeia cresceu e transformou-se num povoado com o nome de Rio Vermelho." (Trecho da nota "Caramuru não deu chabu" do Jornal "A Tarde", 1991).

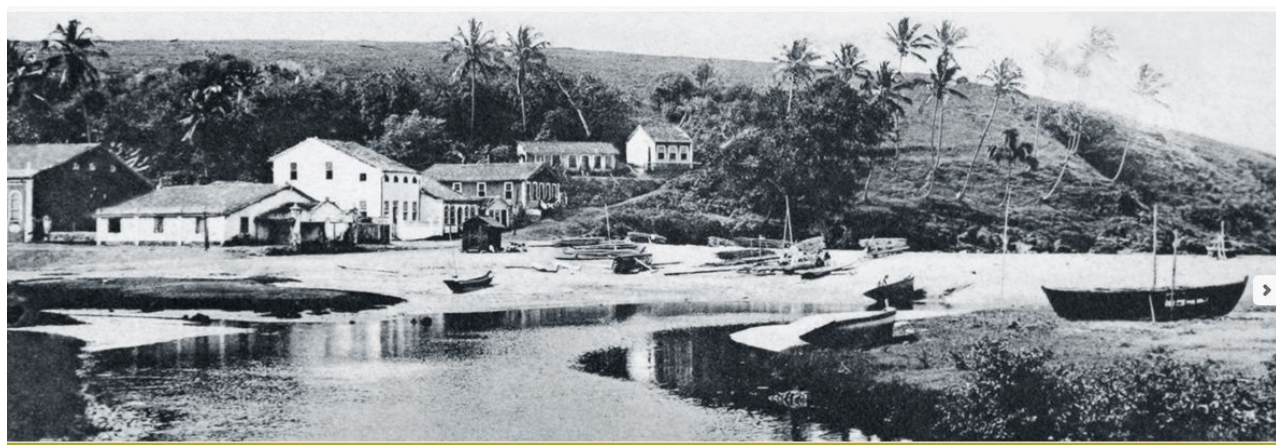

Figura 12: Foto do Rio Vermelho durante o ano de 1907.

Fonte: http://www.amoahistoriadesalvador.com/page/9/. Acesso em 19 Ago.2019. 
O nome Rio Vermelho dá-se devido às terras de barro vermelho encontradas na atual localidade correspondente a avenida Vasco da Gama, que quando chovia trazia as águas tingidas na cor vermelho sangue para desembocar nas proximidades. Sendo uma região de atracamento dos colonos, os primeiros assentamentos acabam por se concentrar na região costeira na qual desenvolve-se a pesca posteriormente como forma de renda para moradores locais entre os quais encontram-se os escravos libertos das fazendas limítrofes.

Até a década de 1950, o que hoje é um bairro densamente ocupado, a princípio era uma vila, no qual concentrava-se a habitação formal (na porção litorânea) e informal (na porção continental), com armazéns, farmácias pontuais e alguns equipamentos culturais tais como os Cine Teatros que no período em questão estavam em seu auge, tendo no Rio Vermelho se instalado o primeiro em 1952 com 778 lugares a princípio sob tutela da empresa A. Cavalcante e posteriormente em 1958 pela Congregação Mariana de São Luis proprietária do Influente Cine Excelsior na Praça da Sé. Os ramais dos bondes elétricos (vide Figura 13) atendiam em parte a comunicação com o centro administrativo e comercial da Cidade, esse ainda situado no perímetro correspondente aos bairros do Pelourinho, Sé,etc.

O retrato das tipologias construtivas das casas, aqui montam a cidade enquanto obra de arte não através da espetacularização de seus ornamentos mas, compreendendo que a tipologia dos telhados bem como o desenho das calçadas, a feira, compunham uma forma de se pensar a produção espacial no momento, ou seja, o que hoje pensa-se como lembrança do Bairro, é naquele instante o próprio presente, memória latente de um período contemporâneo. 


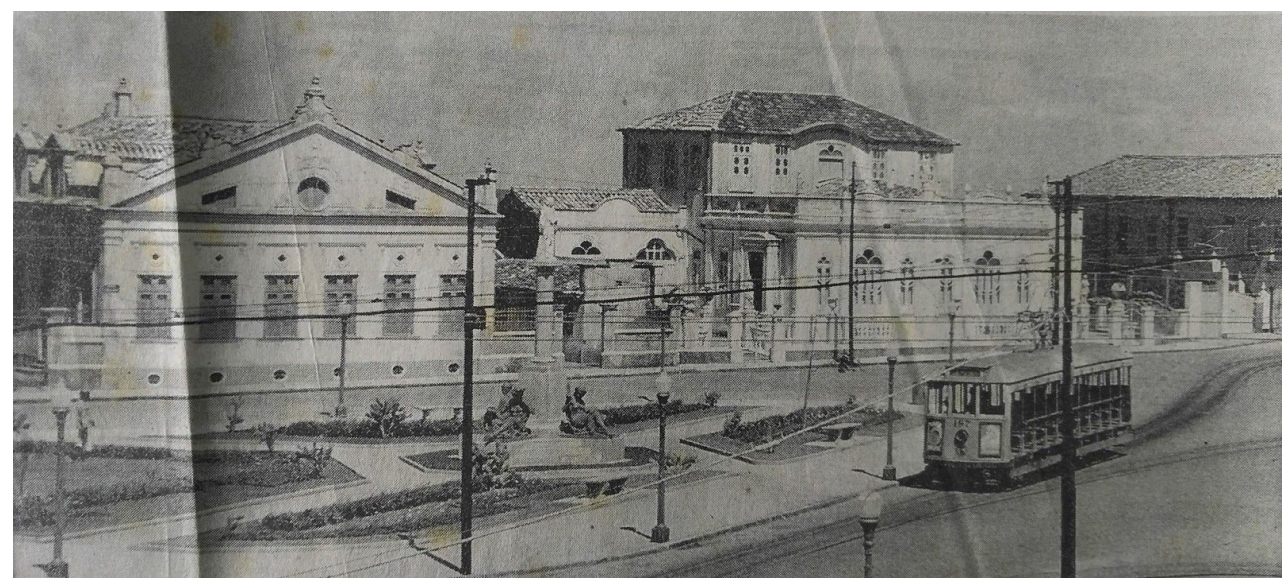

Figura 13: Foto da antiga "Praça Colombo" compondo a matéria do Jornal "A tarde" em 2005. Fonte: Fundação Gregório de Matos (2019).

Com o vetor de expansão urbana impulsionado pela instalação do Centro Industrial de Aratu (CIA) em 1967, e como a eventual descentralização administrativa da capital, a expansão da cidade de Salvador levou a implantação de pequenas fábricas no Rio Vermelho de setores variados desde a produção de papel até a fabricação de balas. O bairro começa a ser visto como destino mais intensivo de veraneio à medida que outras funções lhe acompanham.

A memória da sintonia com a natureza pela dimensão do mar, é tal como as canções de Caymmi que constroem a paisagem de Itapuã enquanto obra de arte de contemplação vivenciada. Essa reiteração imagética, atrai não somente a população de Salvador (algo que existira anteriormente) como igualmente a situada na região metropolitana levando inclusive, no período entre as décadas de 1960 e 1970, alguns artistas influentes como Jorge Amado, Carybé, Mário Cravo, a se instalarem na localidade em busca do almejado no sossego.

Tendo em vista, essas demandas de uso recreativo e de serviço em expansão, e consequentemente ocasionando na necessidade de melhores meios para se chegar ao bairro, o poder público, por intermédio da prefeitura na gestão de Clériston Andrade vai, a partir de 1970, começar a promover obras de "melhoria de circulação urbana" vide figura 14. 


\section{Obras Vão Mudar - Rio Vermelho}

O Prefelto Clériston Andrade val executar obras no Rio Vermelho que reformularão todo o seu sistema vírlo, e ontem pela manhã, depois de aprovar o projeto global, estêve no local com engenheiros municipais discutindo a implantação dos serviços que fará alí no período de seu
govêrno.

Jè na próxima semana o DMMHR iniciará a construção de outra ponte no Rio Vermelho, para criar uma nova vla de acesso a Amaralina, através das ruas Odilon Santos e Maxquês de Monte Santo, que seráo asfaltadas por recomendação do nôvo Chefe do Executivo Municipal, em caráter

Figura 14: Trecho de matéria encontrada no "Jornal da Bahia" em 1970.

Fonte: Fundação Gregório de Matos (2019).

O projeto durante a década de 1970 visava a integração tanto com o Vale do Camarogipe quanto com a Amaralina feita por duas vias de médio porte, a primeira denominada de Avenida Juracy Magalhães Júnior (vide figura 16) situada logo depois do Largo da Mariquita, e a segunda levando o nome do Bairro de Amaralina localizada depois do Quartel general do Exército, predominando nelas, uma tipologia de traçado em paralelas, diferentemente do já existente na Rua da Paciência, essa de dimensão menor e curvilínea em função da tipologia física originária do terreno costeiro, evidenciando duas novas posturas plásticas para a obra de arte (aqui considerada na dimensão do bairro), as primeiras visando costurá-las às novas dinâmicas espaciais impostas pelo capital e as outras mantidas como lastro da configuração imaginária de como se assenta o bairro num princípio, uma espécie de passado brilhante, que esconde na verdade as apropriações subjetivas dos sujeitos que tinham apenas como intencionalidade a ocupação gradual do solo. 
Novas casas e edifícios começam a ser construídos ao longo de ambas as vias tendo como resultado, um aumento populacional entre o período de 1965 e 1980 superior a cinco vezes (vide figura 15) aumentando seis anos depois 1,49\% aproximadamente, fazendo com que o bairro que era antes predominantemente de veraneio, passe a ser o lugar de morada fixa para os comerciantes donos dos novos empreendimentos que ali se instalaram.

\begin{tabular}{|c|c|c|c|}
\hline \multicolumn{4}{|c|}{ POPULAÇÃO DO RIO VERMELHO } \\
\hline \multirow[b]{2}{*}{ ANO } & \multirow[b]{2}{*}{ TOTAL } & \multicolumn{2}{|c|}{ CRESCIMENTO } \\
\hline & & axa Média Anual & Taxa do Período \\
\hline 1950 (estimada) & 3.000 & - & - \\
\hline 1965 (estimada) & 5.000 & $3,5 \%$ & $66,7 \%$ (15 anos) \\
\hline 1980 (estimada) & 25.403 & $11,4 \%$ & $408,1 \%$ (15 anos) \\
\hline 1986 (recenseada) & 37.974 & $6,9 \%$ & $49,5 \%$ (06 anos) \\
\hline 1950/1986 & - & $7,3 \%$ & $1.165,8 \%$ (36 anos) \\
\hline
\end{tabular}

Figura 15: Tabela contendo dados demográficos relativos ao censo de 1987, divulgado no jornal "Correio do Rio Vermelho. Fonte: Fundação Gregório de Matos (2019).

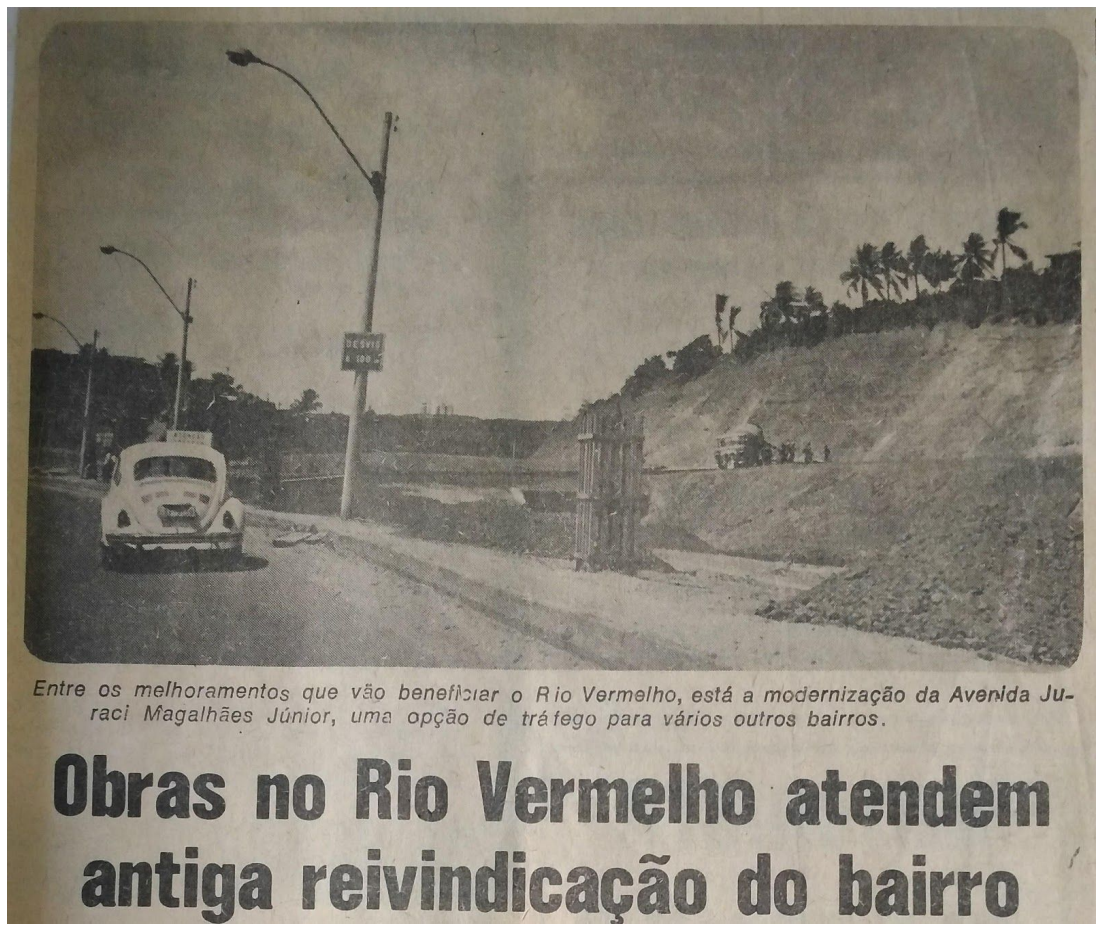

Figura 16: Foto retirada de publicação do Jornal “A tarde" em 1978.

Fonte: Fundação Gregório de Matos (2019). 
As expansões viárias por si mesmas não foram claramente capazes de dissolver as demandas urbanas ainda existentes, outras mais foram criadas tais como o aumento da especulação imobiliária e de inúmeras reformas nas casas remanescentes que vieram a descaracterizar boa parte da leitura da paisagem urbana existente. A ausência de políticas de salvaguarda para áreas de uso e caráter patrimonial, não apresentavam diretrizes claras quanto a orientação de como as intervenções deveriam ser feitas tal como existiam brechas na Lei de Ordenamento, Uso e ocupação do Solo (LOUOS) o que nos faz pensar na pungência do momento em se trazer o passado para o presente a todo custo, negando a relação do sujeito com a cidade enquanto obra de arte à medida que, rompe uma temporalidade de memória de muitos dos antigos moradores para colocar no lugar a lembrança do sossego enquanto capital simbólico utilizado pelo mercado imobiliário.

As etapas de requalificação urbana, em especial no Largo de Santana e da mariquita, posteriores a esse período são reflexos da mesma tentativa de reconstituição de uma lembrança, visto que a memória acaba sendo liquidada pela oscilação do fluxo de capital existente. Artistas se instalam e posteriormente vão embora, praças são construídas e depois abandonadas pela gestão pública (vide figura 17) levando-nos a entender que o capital cultural no Rio Vermelho é o real interesse. A apropriação dos símbolos oriundos das festas de Santo, a revitalização do Largo de Santana batizada "simbolicamente" como "Largo da Dinha" a posteriori, são mecanismos que mostram que a todo momento existe um simbolismo que atrai bares, casas de shows e restaurantes que visam na vida noturna a oportunidade de continuação de uma celebração que antes se concentrava no dia 02 de Fevereiro. 


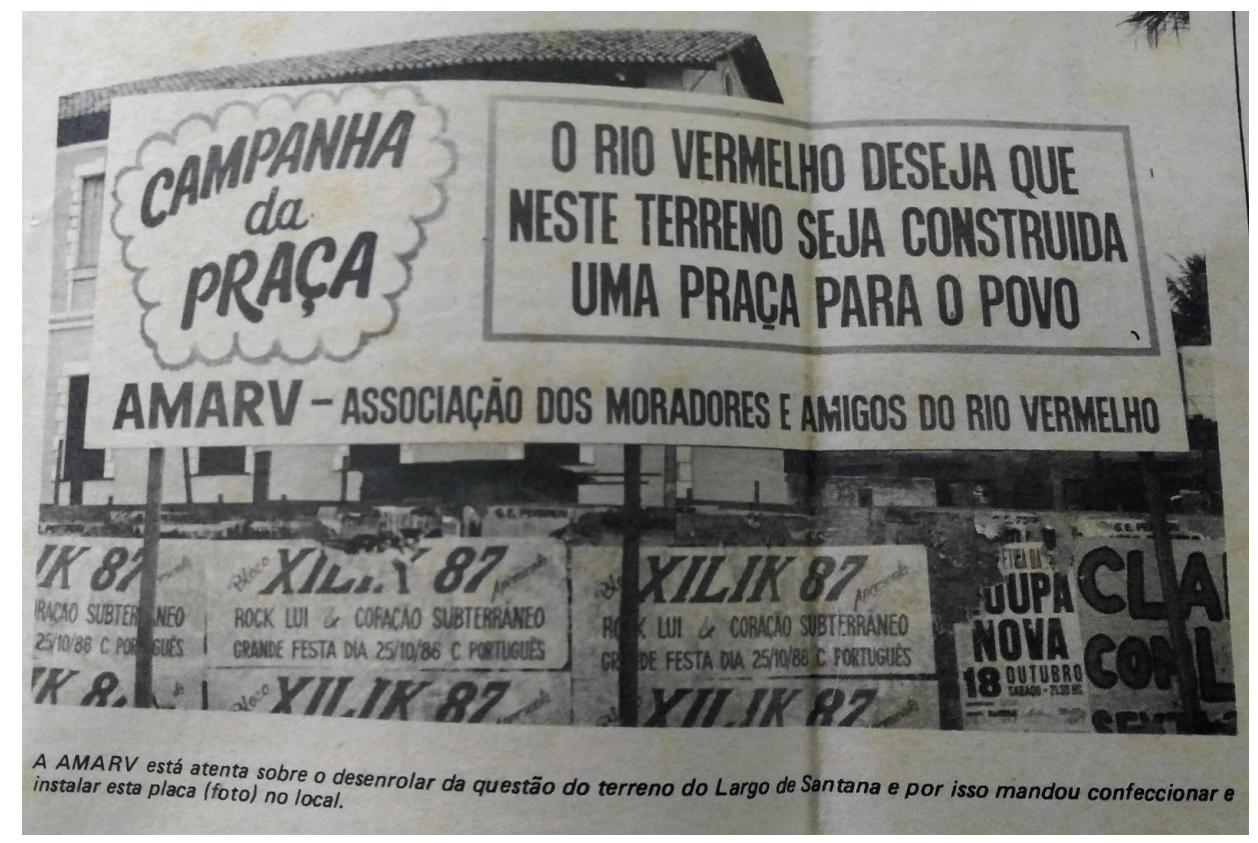

Figura 17: Foto com destaque o cartaz da (AMARV) compondo a matéria do Correio do Rio Vermelho em 1987. Fonte: Fundação Gregório de Matos (2019).

Quanto aos monumentos encontrados no percurso da poligonal, dia e noite, nota-se a distinção técnica entre as obras, que vão de estátuas de bronze, a estátuas efêmeras, de material reciclado; que brincam ao transformar seus aspectos plásticos, ou que permitem ao sujeito brincar com a história ao se retratar junto a obra. Existe uma hiperestimulação na variedade de elementos culturais materiais e imateriais, mas que, distanciam os sujeitos à medida que os impõem há uma vivência temporal de inerente loucura e sinestesia de diferenças, não nos encontramos, pois somos inclusive convidados a nos perder em meio ao consumo de bebidas alcoólicas que embasam nossa visão.

Talvez aí se encontre o problema. Tais diferenças nas obras, não passam de cenografia produzida para reconfiguração do espaço enquanto valoração do capital. Deste modo pouco a pouco sujeito e espaço, atrelados na possibilidade de encontrar-se nas diferentes percepções promovidas pelo espaço, vão se desassociando no cenário, que a memória não consegue apreender, por conta da fluidez necessária ao capital. 


\section{Para não concluir...}

Além do alargamento da relação entre cidade, arte e lugar, que tem por síntese o sujeito, e o seu modo próprio de estar no espaço, os conceitos de memória e lembrança fazem um paralelo aos anteriores, servindo de base analítica que justifica e permite entender a tríade principal. Assim, passamos a compreender que a mudança na função social da arte determina a urgência na revisão do termo contemplação/observação que, no âmbito construído nesta reflexão tem a necessidade de situar-se enquanto mistura silenciosa do sujeito com o objeto que, ao construí-lo se constroem. Não obstante, nesta construção, onde sujeito e obra se significam é que a memória se faz então, podemos afirmar: a elevação do espaço a lugar acontece à medida que existe uma memória do mesmo.

Já, o sentido de lembrança pressupõe a negação da relação entre o sujeito e o lugar, que se faz na outrora, podendo nunca ter sido - como aponta a análise da obra "A Mãe Baiana"; podendo se fazer, ainda no não ser - o que foi demonstrado na desconstrução da obra "As Meninas do Brasil"; e por fim. o que se dá no conjunto de obras do Rio Vermelho, quando se faz confundir a lembrança com a memória em favor de uma cultura re-apropriada, como instrumento do capital.

Contudo que foi observado e analisado, podemos verificar que a natureza da obra de arte na cidade existe. Mas, não se dá somente quando a mesma é vista enquanto técnica e forma, faz-se necessário a relação entre o sujeito e o objeto, ou seja, entre o sujeito e a cidade ora enquanto espaço vivido, ora enquanto representado por objetos de arte.

Tais objetos, ainda que não sejam a condição fundamental da revelação da natureza da cidade, promovem a polaridade entre o sujeito e o espaço, visto que possibilitam a construção da memória do mesmo, e deste modo a relação de pertencimento. 
As obras escolhidas constituem relações bastantes distintas com o espaço, o que possibilita a afirmação que cada obra de modo isolado não necessariamente rompe com as relações espaciais já postas, ou reconstituem a identidade do lugar. Isto porque mesmo havendo interação entre o sujeito e a obra, esta última precisa estar interagindo com o espaço, para que possa ser ponte entre estes.

Assim, há espaços que por seu ordenamento físico e cultural, não possibilitam a obra de ser percebida como parte integrante que compõe o objeto que é a cidade. Deste modo então, a obra só consegue manter relação com o sujeito, e seu entorno continua distante da percepção de objeto de arte.

Em outros casos, a obra de arte não mantém nenhuma relação com o sujeito, a não ser no âmbito da sua própria negação, que nesta temporalidade nos permite afirmar a maximização de outros valores que não o espaço vivido, e não necessariamente tão concreto quanto ele. Sendo podemos concluir que a supremacia das relações de capital, simbólico ou não, quando vividas de modo imperativo rompem com a possibilidade de relação entre o sujeito e o espaço, de tal modo que faz desaparecer qualquer pressuposto capaz desta reconstrução. Ou seja, a forma como o capital econômico se impõe no espaço impossibilita a revelação da natureza da cidade, à medida que enclausura o sujeito numa bolha temporal e num modo de apropriação específico.

Ainda podemos dizer que, mesmo quando a obra é posta em um espaço cujas relações históricas e culturais permitem a sua contemplação/observação e deste modo a ressignificação do espaço da obra e do sujeito, esta não o ressignifica de fato! Mas antes, sobrepõe uma relação de capital simbólico, reforçando uma identidade local criada pelo poder. Sendo assim as obras analisadas deste modo, constituem o espaço enquanto lugar apenas aparentemente.

A revelação da gênesis da cidade enquanto objeto de arte, portanto a percepção do espaço enquanto lugar, só é possível pelas 
vias da obra de arte, se a percebemos como uma construção social, determinada no fazer cotidiano que pouco a pouco, desprende-se da obra e revela a cidade enquanto objeto maior, dotada de técnica, forma, e subjetividade. 


\section{Referências}

ARGAN, Giulio Carlo. História da arte como história da cidade. São Paulo: Martins Fontes, 1992.

BAUDRY, Patrick. O pornô como experiência urbana. Cadernos PPGAU/FAUFBA, v. 7, p. 55-65, 2008.

BENJAMIM, Walter. Magia e técnica, arte e política: ensaios sobre literatura e história da cultura. São Paulo: Brasiliense, 1994.

BOURDIEU, Pierre. A distinção. São Paulo: Edusp, 2007.

CARDOSO FILHO, Carlos Antônio. A subjetividade, o Fora e a cidade: repensando o sujeito, o espaço e a materialidade. Fractal: Revista de Psicologia, v. 28, n. 2, p. 242-251, 2016.

CARDOSO, Wilson Benes de Oliveira; VALADARES, Jorge de Campos. O ritmo das transformações, a exclusão, a legislação urbana e a condição humana na cidade. Ciência \& Saúde Coletiva, v. 7, p. 313-323, 2002.

CARTAXO, Zalinda. Arte nos espaços públicos: a cidade como realidade. O Percevejo Online, v. 1, n. 1, 2009.

ECO, Umberto. 1968. A estrutura ausente, 1976.

EWALD, Ariane Patrícia; GONÇALVES, Rafael Ramos; BRAVO, Camila Fernandes. O espaço enquanto lugar da Subjetividade. Revista Mal-Estar e Subjetividade, v. 8, n. 3, p. 755-777, 2008.

FERRARA, Lucrécia DAlessio. As mediações da paisagem. Líbero, São Paulo, v. 29, n. 15, p. 43-50, 2012.

FISCHER, Ernst. A necessidade da arte: uma interpretação marxista. Zahar, 1967.

FREITAS, S. Arte, Cidade e Espaço Público: perspectivas estéticas e sociais. Artigo científico apresentado no I Enecult - Encontro de Estudos Multidisciplinares em Cultura, Facom-UFBA, 2005.

FREUD, Sigmund. O mal-estar na civilização. LeBooks Editora, 2019.

GARCÍA CANCLINI, Néstor et al. O patrimônio cultural e a construção imaginária do nacional. Revista de Patrimônio Histórico e Artístico Nacional, v. 2, p. 95-115, 1994.

GOMBRICH, Ernest Hans: TORROELLA, Rafael Santos; SETÓ, Javier. Historia del arte. Nueva York: Phaidon, 1997.

GUSMÃO, Roney. Requalificação pela desqualificação: o discurso da reurbanização no "novo" Rio Vermelho. GEOUSP: Espaço E Tempo (Online), v. 21, n. 2, p. 531-549, 2017.

KERTÉSZ, Eliana. Perfil \& Opinião com Eliana Kertész [jan. 2014]. Entrevistadora: Denny Fingergut. Salvador: IRDEB, 2014. Entrevista concedida ao Programa Perfil \& Opinião da TVE Bahia. Disponível em: < http://www.irdeb.ba.gov.br/tve/catalogo/

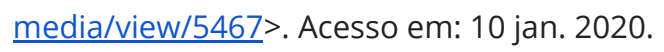


LYNCH, Kevin; CAMARGO, Jefferson Luiz. A imagem da cidade. São Paulo: Martins Fontes, 1997.

MOASSAB, Andréia; REBOUÇAS, Renato. Arte e cidade: construindo territorialidades. Seminário arte e cidade, v. 1, 2006.

POLLAK, Michael. Memória, esquecimento, silêncio. Revista estudos históricos, v. 2, n. 3, p. 3-15, 1989.

POLLAK, Michael. Memória e identidade social. Revista Estudos Históricos, v. 5, n. 10, p. 200-215, 1992.

SANTOS, Carlos Nelson Ferreira dos. Preservar não é tombar, renovar não é pôr tudo abaixo. Revista Projeto, v. 86, p. 59-63, 1986.

SANTOS, Milton. A natureza do espaço: técnica e tempo, razão e emoção. Edusp, 2002.

SANTOS, Milton. Metamorfoses do Espaço Habitado. São Paulo: Editora Hucitec,1988. SANTOS, Milton. O Lugar: encontrando o futuro. Revista de urbanismo e arquitetura, v. 4, n. 1, 1996.

TEIXEIRA, Arq Marina Coêlho; SANTOS, Mg Arq Jacileda Cerqueira. Leituras possíveis: a paisagem do Largo da Mariquita. Arquisur Revista, v. 5, n. 7, p. 96-111, 2015.

VELAME, Fábio Macêdo. Orixás nos espaços públicos de Salvador: um processo de dessacralização-estetização-espetacularização do patrimônio afro-brasileiro. 2009. ZORZO, Francisco Antônio. A visualidade urbana contemporânea como campo de estudos interdisciplinares. A Cor das Letras, v. 13, n. 1, p. 61-78, 2017.

\section{Resumo}

O seguinte artigo analisa a necessidade de reunião dos conceitos de cidade, lugar e arte; a saber de Argan e Santos respectivamente, partindo das mudanças na concepção da arte contemporânea, onde é proposto que é na relação entre o sujeito fenomenológico e a obra que brota o objeto artístico. Não são negadas as várias possibilidades de linguagens da arte postas no espaço urbano contudo, se escolhe restringir a análise empírica a duas esculturas e um traço poligonal onde a arte constitui a identidade local e suas relações com o espaço vivido. São utilizadas metodologias próprias da antropologia urbana construindo reflexões dialéticas que surgem a partir da exploração conceitual mesclando dados qualitativos com os quantitativos dos espaços analisados. Conclui, afirmando que a cidade enquanto obra de arte se mantém em estado de latência, até que a relação entre o sujeito e o espaço à determine de fato como objeto desta natureza; portanto, é a medida em que a cidade se torna um lugar que esta passa a ser percebida como arte, ou ainda, é na medida que o objeto artístico se relaciona com o sujeito 
DOI:10.20396/urbana.v11i3.8656273

que o sentido de lugar emerge. Afirma assim, que a técnica e a forma são elementos necessários, mas não suficientes.

Palavras-chave: Arte. Cidade. Sujeito. Lugar. Latência.

\begin{abstract}
The article presented here arises from the need to bring together the concepts of city, place, and art delivered by Argan and Santos respectively, starting from the changes in the conception of contemporary art, where it is in the relationship between the phenomenological subject and the artwork, that springs the artistic object. The various possibilities of art languages posed in the urban space are not denied, however, this work chooses to restrict the empirical analysis to two sculptures and a polygonal trait where art constitutes the local identity and its relations with the lived space. Methodologies typical of urban anthropology are used, basically to construct dialectical reflections that arise from conceptual exploration, qualitative and quantitative data in the analyzed spaces are merged. The text concludes by postulating that the city as a work of art remains in a state of latency until the relationship between the subject and space determines it as an object of this nature; Therefore, it's to the extent that the city becomes a place that it becomes perceived as art, or even, as the artistic object relates to the subject that the sense of place emerges. Technique and form are necessary but not sufficient elements.
\end{abstract}

Keywords: Art. City. Subject. Place. Latency.

\title{
Resumen
}

El siguiente artículo examina la necesidad de reunir los conceptos de ciudad, lugar y arte; a saber, Argan y Santos, respectivamente, a partir de los cambios en la concepción del arte contemporáneo, donde se propone que es en la relación entre el sujeto fenomenológico y el trabajo del que surge el objeto artístico. No se niegan las diversas posibilidades de los lenguajes de arte ubicados en el espacio urbano, sin embargo, uno elige restringir el análisis empírico a dos esculturas y un rasgo poligonal donde el arte constituye la identidad local y sus relaciones con el espacio vivido. Las metodologías típicas de la antropología urbana son utilizadas para construir reflexiones dialécticas que surgen de la exploración conceptual, mezclando datos cualitativos y cuantitativos en los espacios analizados. Concluye afirmando que la ciudad como obra de arte permanece en un estado de latencia, hasta que la relación entre el sujeto y el 
DOI:10.20396/urbana.v11i3.8656273

espacio realmente la determine como un objeto de esta naturaleza; Por lo tanto, es en la medida en que la ciudad se convierte en un lugar que se percibe como arte, además, cuando el objeto artístico se relaciona con el tema que emerge el sentido del lugar. Por lo tanto, establece que la técnica y la forma son elementos necesarios, pero no suficientes.

Palabras clave: Arte. Ciudad. Sujeto. Lugar. Latencia. 